\title{
The influence of the financial logic in the National Quality Award
}

\section{A influência da lógica financeira no Prêmio Nacional da Qualidade}

\author{
Marina Borges Lima Fantti ${ }^{1}$, Julio Cesar Donadone ${ }^{1}$ [(] \\ ${ }^{1}$ Universidade Federal de São Carlos- UFSCar, Núcleo de Sociologia Econômica e das Financas- NESEFI, \\ São Carlos, SP, Brasil. E-mail: ma.sanca@hotmail.com; donadojc@uol.com.br
}

How to cite: Fantti, M. B. L., \& Donadone, J. C. (2020). The influence of the financial logic in the National Quality Award. Gestão \& Produção, 27(2), e5052. https://doi.org/10.1590/0104-530X5052-20

\begin{abstract}
The financialization process resulted in a change in the discourse of the actors involved in quality management, who began to incorporate concepts of financial logic as a way to meet the demands of shareholders capitalism and guarantee legitimacy. Thus, through a documentary research, we sought to investigate the influence of the financial logic in the National Quality Award, analyzing the versions of the Management Excellence Model used in the awards cycles and the companies awarded in the period from 1992 to 2016 . The results demonstrated the incorporation of financial logic concepts in the versions of the Management Excellence Model; the predominance of award-winning companies from the electric energy sector, which have been privatized; the existence of board interlockings in the winning organizations; and presidents who have professional experience in financial areas and postgraduate degree in finance, which is the profile most demanded and valued in the finance conception of control.
\end{abstract}

Keywords: Financialization; Shareholder value; Financial logic; Management Excellence Model; National Quality Award.

Resumo: O processo financeirização resultou na alteração do discurso dos atores envolvidos com a gestão da qualidade, que passaram a incorporar conceitos da lógica financeira como forma de atender as transformações no controle coorporativo das organizações, em especial ação dos acionistas e seus representantes, e garantir sua legitimidade. Assim, por meio de uma pesquisa documental, buscou-se investigar a influência de elementos de gestão da lógica financeira no Prêmio Nacional da Qualidade, sendo analisadas as versões do Modelo de Excelência da Gestão utilizadas nos ciclos de premiação e as empresas premiadas no período de 1992 a 2016. Os resultados demonstraram a incorporação de conceitos da lógica financeira nas versões do Modelo de Excelência da Gestão; o predomínio de empresas premiadas do setor de energia elétrica, que passaram pela onda de privatizações; a existência de board interlockings entre as organizações premiadas; e de presidentes com carreira em áreas financeiras e que buscaram pós-graduações em finanças, sendo o perfil mais exigido e valorizado na concepção financeira de controle.

Palavras-chave: Financeirização; Geração de valor aos acionistas; Lógica financeira; Modelo de Excelência da Gestão; Prêmio Nacional da Qualidade.

Received Aug. 08, 2018 - Accepted Oct. 17, 2018

Financial support: None. 


\section{Introduction}

The social construction of the shareholder value ideology involved many players, for instance: institutional and activist investors; legislators, lobbyists and other advocates of financial deregulation; market analysts, such as risk agencies and business press; financial-economist theoreticians and business schools; consulting companies and business advisory industry in general; and fund managers (Saltorato \& Benatti, 2017). These players begun to held privileged positions in the new field structure which conferred them the ability to exercise several kinds of power over other stakeholders, such as the professional managers, who had to align their discourses with the shareholder value ideology, reproducing its most emblematic values in their strategies and, thus, symbolically manage the capital market pressure in their favor, through some doses of performative acts (Goldstein, 2012; Westphal \& Zajac, 2001; Zajac \& Westphal, 2004).

The process of dominance of the financial actors and the financial logic to the detriment of the production logic resulted in the adequacy of the practices disseminated by the organizations, for instance the change in the discourse of the actors involved in quality management, which was initially focused on the production logic, through the search for increased productivity and quality. It began to incorporate concepts of financial logic, in order to meet the demands of capitalism of shareholders and guarantee legitimacy (Donadone \& Fantti, 2014).

In this context, the objective of this paper is to explore the influence of the elements of management based on the financial logic in the Brazilian National Quality Award.

The Brazilian National Quality Award was chosen to be one of the most recent and comprehensive approaches to quality management, that emerged in the 1990s as a way to improve the quality and competitiveness of Brazilian companies. This award was intended in the first years of implementation to reflect the "state of the art of the total quality management", having as main reference at that time the criteria of excellence of the North American version of the award called Malcolm Baldrige National Quality Award.

A documentary research was carried out, which involved the following steps: a) analysis of the influence of the financial logic on the versions of the Management Excellence Model used in the award cycles of the Brazilian National Quality Award from 1992 to 2016; b) analysis of the influence of the financial logic on the profile of the winning companies in the Brazilian National Quality Award from 1992 to 2016; c) analysis of the occurrence of board interlocking, that is, the existence of common members of corporate board of directors and presidents in the winning companies, which could have influenced the diffusion and adoption of the Management Excellence Model and participation in the Brazilian National Quality Award; d) analysis of the professional origin and the educational background (graduate and postgraduate levels) of the executive presidents active in the awards years of these companies.

The analysis of the influence of the financial logic on the winning companies is relevant to the extent that there are few empirical studies that demonstrate the influence of the financial logic in the organizations (Erturk et al., 2008; Froud et al., 2012). In addition, most of these studies focus on analyzes of North American organizations (Andersson et al., 2010; Fligstein, 1990; Froud et al., 2006; Froud et al., 2012). 
The analysis of the Brazilian context is relevant to complement the empirical studies carried out, which analyzed the influence of financial logic in organizations on different aspects, such as: degree of vertical integration, social capital, actors' performance, production management, management systems, mergers and acquisitions, organizational restructuring (Donadone \& Cenedezi, 2016; Matsuda, 2015; Mundo, 2011, 2012; Saltorato et al., 2016; Saltorato \& Benatti, 2017; Souza, 2007; Zanarotti, 2012).

In addition, the analysis of the occurrence of board interlocking, that is, the practice of interconnected boards of directors, is important to demonstrate how this practice can influence the adoption of certain reference models and management practices. Besides this, the analysis of the professional origin of the presidents, in terms of their educational and professional backgrounds before becoming president, is relevant to confirm the tendency addressed by Fligstein (1990) and Matsuda (2015) that in the financial conception of control professionals of financial origin tend to have a prominent position.

This paper is organized in six parts, including this introduction. The second part, presents a literature review on the organizational impacts resulting from financial logic. The third part, presents a literature review of the Brazilian National Quality Award. The forth part, details the research method. The fifth part, presents the results obtained in the analysis of the influence of financial logic on the Brazilian National Quality Award. Finally, the conclusions are presented.

\section{Organizational impacts resulting from financial logic}

At the beginning of the 1990s, there was a significant increase, mainly in the United States and European Union, of the influence of financial markets on corporations due to changes in economic policies, which generally adopted more liberal regimes characterized by waves of privatization of large industrial and financial enterprises and the liberation of financial systems (Plihon, 2003).

In this context, researchers perceived an important change in contemporary capitalism, which contributed to the search for new conceptual tools (Engelen, 2008). As a result, since the 2000s, there has been an increase in the number of publications in various fields of knowledge that use the term "financialization" to describe a series of structural changes in the advanced political economies, in organizations and in people's everyday life, which seeks to privilege the financial logic to the detriment of the production logic.

In general, the various definitions for the term financialization are tied to three levels of analysis of the phenomenon (van der Zwan, 2014). The first level focuses on analyzing the macro-environment that considers financialization as the emergence of a new regime of accumulation led by finance. It prioritizes the financial instruments rather than the productive instruments as a way of obtaining wealth (Arrighi, 1994; Boyer, 2000; Braga, 1997; Chesnais, 1996, 2005; Epstein, 2005; Thompson, 2013).

The second level centres on the analysis of the organization that considers the emergence of shareholder value as the main guiding principle of corporate behavior. In order to generate shareholder value, organizations focus on the short-term perspective, core business, the use of downsizing strategies, mergers and acquisitions, the use of management practices those ensure compliance with corporate governance principles among others (Davis, 2009; Fligstein, 1990; Froud et al., 2006; Jürgens et al., 2000; Lazonick \& O'Sullivan, 2000; Widmer, 2011). 
The third level focuses on the analysis of the individual which considers the influence of the financialization process on everyday life. The transition of finance into daily life has been made possible by the democratization of finance, whereby financial products and services have been made available to large parts of the population (Erturk et al., 2007, 2008; Montgomerie, 2006), thus arising the "investing subject" (Aitken, 2007; Martin, 2002).

This paper is based on the organization's level of analysis that examines the ascendancy of the shareholder value orientation as a guiding principle of corporate behavior. First, it considers how financial markets exert pressures on non-financial corporations, and the managers running them, to adopt business practices promoting shareholder value. Second, it evaluates how these corporations establish shareholder value by diverting financial market pressure onto other constituents of the firm (van der Zwan, 2014).

Davis (2009) analyzed the eras experienced by the North American organizations, which demonstrated the rise of the influence of the financial markets, the prevalence of financial logic and shareholder value orientation in the organizations.

The first era experienced by organizations was called "financial capitalism", which emerged at the turn of the nineteenth to the twentieth century with the wave of acquisitions and mergers, characterized by the influence of bankers in the management of large organizations. For the public perspective, these were cartels controlled by Wall Street financiers (Davis, 2009).

The second era was called "managerial capitalism", which emerged from the 1920 s with the stock market boom and increase of public participation in organizations (Davis, 2009).

The third era was called "shareholder capitalism", which came with the wave of takeover processes since the 1980s, resulting in stronger influence of the financial market institutional investors in organizations (Davis, 2009). They began to question the way professional managers performed, insofar as they were seen as responsible for the slowness in the corporate communication process, appropriation of a considerable share of shareholders' dividends, through unnecessarily high salaries, benefits, and adoption of business strategies that favored their stability in employment, instead of maximizing return to shareholders (Donadone, 2009).

Consequently, professional managers had to reinvent and reorient their discourses and actions to the ideology of shareholder value creation, symbolically managing capital market pressure in their favor (Goldstein, 2012; Saltorato \& Benatti, 2017; Zajac \& Westphal, 2004).

This phenomenon can be portrayed as a social constructionist of a bourdieusian organizational field. In this process, the most well-positioned capital market actors legitimize the new functioning rules, or its habitus (Bourdieu, 2010), defining values, beliefs, myths and rituals to be perceived as symbols of value creation, which are reproduced by the discourses of the actors that occupy less privileged niches within the field.

Thus, in the efforts to demonstrate the shareholder value creation, the organizations managers use the symbolic-performative power and narratives, despite the distance between their promises (creating shareholder value) and the outcomes obtained (only reducing labor costs) (Froud et al., 2006).

To sum up, due to the need to create shareholder value and adhere to the principles of corporate governance, the organizations have adopted a series of management strategies and practices related to the financial logic, such as: 
- Preference for professionals with financial background to exercise command of organizations, unlike previous conceptions of control, from which the presidents came from operations or sales areas (Fligstein, 1990; Matsuda, 2015);

- Focus on obtaining economic-financial results in the short term, emphasizing the need for managers to have agility in decision making (Lazonick, 2008);

- Use of variable remuneration linked to financial and the stock market performance (Grün, 2004);

- Focus on capital appreciation by financial logic rather than production logic, as the gains from financial strategies and capital markets are usually higher than those obtained in improvements in production processes (Erturk et al., 2008);

- Strengthening of the corporate governance structure;

- Use of interconnected boards of directors, resulting from the social relationship created between two or more companies by including the same professional on the board of directors, named board interlocking by the financial literature (Fich \& White, 2005).

\section{Brazilian National Quality Award}

The quality awards were created to encourage the development of innovative quality management concepts and aim to recognize the organizations that meet certain reference models, which include the main practices of Total Quality Management (Boulter et al., 2013; Casado \& Legaz, 2010; Chaudary et al., 2015; Hendricks \& Singhal, 1996, 1997; Nair, 2006).

During the last thirty years, the most widely-recognized quality awards were the Deming Prize from Japan, the Malcolm Baldrige National Quality Award from United States and the European Quality Award from Europe, which their excellence models are the basis for most of quality awards (Boulter et al., 2013; Chaudary et al., 2015; Corredor \& Goñi, 2010; Grigg \& Mann, 2008; Mavroidis et al., 2007; Zhang \& Xia, 2013).

In Brazil, the National Quality Award (NQA) was created in 1992 under the administration of the so-called Foundation for the National Quality Award, which later became known as the National Quality Foundation (NQF). The 1st award cycle was based on the excellence criteria of the Malcolm Baldrige National Quality Award, which evaluate the companies, without prescribing methods and management tools.

From its creation in 1992 to 2016, 26 awards cycles were held, with the participation of 522 candidate companies and 7156 examiners. This resulted, in recognition of 66 companies with trophies as winning companies, magna cum laude (applies to the companies that were awarded in one cycle and maintained the level in the consecutive cycle) and summa cum laude (applies the companies that were awarded one cycle and maintained the level of excellence for another two consecutive cycles) (FNQ, 2015, 2016).

The NQA uses the Management Excellence Model (MEM) as a reference model, which is a trademark of the National Quality Foundation. This is a model for quality management, which seeks to reflect a world class business management system.

The MEM versions used until 2016 were composed of fundamentals of excellence and criteria of excellence. The fundamentals intend to be the pillars upon which the management of World Class organizations should be based. Therefore the criteria were designed as parameters which should be used to put the fundamentals into 
practice as structured items and requirements which allow the key-concepts of management excellence to be easily understood (FNQ, 2013).

The criteria of excellence include a number of managerial processes required, which investigate "how" the organization performs certain managerial activities in a systematic way, that is, what are and how the management practices that the organization adopts to attend to these managerial processes, which aim to meet the requirements of all stakeholders and generate results for the business.

Based on the Brazilian quality movement in the 1990s, the National Quality Foundation (NQF) and the National Quality Award (NQA) sought to reflect:

- The state of the art of total quality management from 1990 to 2004;

- The state of the art in quality of management from 2005 to 2015;

- The state of the art in excellence management from 2016 to 2017;

- The state of the art in transformation management from 2018.

This demonstrates that progressively the NQF and the NQA have gone from focusing on quality management to focusing on transformation management, being evidence of the loss of the strength of the quality movement in Brazil and the need for the NQF to incorporate other tendencies, such as those associated with diffusion of financial logic.

The influence of the financial logic is present in the quality awards legitimation process, being evidenced mainly by the various studies that correlate the adoption of the management excellence models and the quality awards achievement with the organizational performance, being used in the analyzes: traditional financial indicators, financial indicators focused on the shareholder value creation and non-financial indicators. These studies reinforce the existence of "narratives" used to demonstrate the actions implemented by organizations to meet the demands of shareholder capitalism.

In Brazil, there are few studies that correlate the quality awards achievement with organizational performance. Academic surveys related to this topic have been paradoxical, with papers indicating: positive correlation (Bassan, 2016; Bassan \& Martins, 2015), negative correlation (Pignanelli, 2007) and both (Oliveira \& Martins, 2008). This picture of inconclusiveness is related to the fact that performance is the result of a set of variables that go beyond quality and excellence management.

\section{Research method}

The adopted research method consisted of an exploratory study based on secondary data. The data was collected through documentary research aiming at investigating the characteristics and strategies related to the financial conception of control present in the National Quality Award (NQA), either in the reference model adopted, or in the organizations recognized for excellence in management, for having been successful in the awards cycles. The sources of data collection were the annual and sustainability reports; the management reports of the award-winning companies available on the National Quality Foundation (NQF) website, the information available on the companies' websites, and in the business press. The study focused on the analysis of the award-winning organizations from the first edition of the event in 1992 until 2016. In sum, 47 companies were analyzed, 11 of which received the award more than once, representing 66 award-winning companies, as seen in Chart 1. 
Chart 1. Brazilian National Quality Award winners from 1992 to 2016.

\begin{tabular}{|c|c|}
\hline Year & Brazilian National Quality Award winners \\
\hline 1992 & IBM - Sumaré Unit \\
\hline 1993 & Xerox \\
\hline 1994 & Citibank - Global Consumer Bank Unit \\
\hline 1995 & Serasa S.A. \\
\hline 1996 & Alcoa - Poços de Caldas Unit \\
\hline 1997 & $\begin{array}{l}\text { Weg - Motors Unit; Copesul - Companhia Petroquímica do Sul; Citibank - Corporate } \\
\text { Banking Unit }\end{array}$ \\
\hline 1998 & Siemens - Telecommunications Unit \\
\hline 1999 & Cetrel S.A. - Empresa de Proteção Ambiental; Caterpillar \\
\hline 2000 & Serasa S.A. \\
\hline 2001 & Bahia Sul Celulose S.A. \\
\hline 2002 & $\begin{array}{l}\text { Gerdau (Aços Finos Piratini Unit); Politeno Indústria e Comércio S.A.; Irmandade } \\
\text { Santa Casa de Misericórdia de Porto Alegre }\end{array}$ \\
\hline 2003 & Dana Albanus (Cardans Unit); Escritório de Engenharia Joal Teitelbaum \\
\hline 2004 & Belgo (Arcelor) - (Juiz de Fora Unit) \\
\hline 2005 & $\begin{array}{l}\text { Companhia Paulista de Força e Luz; Petroquímica União S.A.; Serasa S.A.; } \\
\text { Suzano Petroquímica S.A. }\end{array}$ \\
\hline 2006 & Belgo Siderurgia S.A. (Arcelor) (Monlevade Unit) \\
\hline 2007 & $\begin{array}{l}\text { Albras Alumínio Brasileiro S.A.; Fras-le S.A.; Gerdau (Riograndense Unit); } \\
\text { Petróleo Brasileiro S.A.; Promon S.A. }\end{array}$ \\
\hline 2008 & CPFL Paulista; Suzano Papel e Celulose \\
\hline 2009 & $\begin{array}{l}\text { AES Eletropaulo; Brasal Refrigerantes; CPFL Piratininga; Volvo do Brasil } \\
\text { Veículos Ltda (Trucks Unit) }\end{array}$ \\
\hline 2010 & AES Sul; Elektro Eletricidade e Serviços S.A. \\
\hline 2011 & $\begin{array}{l}\text { Companhia Energética do Ceará; Companhia Paulista de Força e Luz; Centrais } \\
\text { Elétricas do Norte do Brasil S.A.; Rio Grande Energia S.A. }\end{array}$ \\
\hline 2012 & $\begin{array}{l}\text { Cemig Geração e Transmissão S.A.; AES Eletropaulo; Suspensys Sistemas } \\
\text { Automotivos Ltda; Energisa Paraíba Distribuidora de Energia S.A.; Volvo do } \\
\text { Brasil Veículos Ltda (Trucks Unit); AES Tietê S.A. }\end{array}$ \\
\hline 2013 & Sabesp Norte; Sabesp Leste; Elektro Eletricidade e Serviços S.A. \\
\hline 2014 & $\begin{array}{l}\text { Embraer S.A.; AES Sul; Companhia Energética do Ceará; Centrais Elétricas do } \\
\text { Norte do Brasil S.A.; Master Sistemas Automotivos Ltda; Promon Logicalis }\end{array}$ \\
\hline 2015 & $\begin{array}{l}\text { Brasal Refrigerantes; Volvo do Brasil Veículos Ltda; Embraer S.A. (Magna Cum } \\
\text { Laude); Centrais Elétricas do Norte do Brasil S.A. (Magna Cum Laude) }\end{array}$ \\
\hline 2016 & $\begin{array}{l}\text { Elektro Eletricidade e Serviços S.A; Sabesp Sul; Senac RS; Brasal Refrigerantes } \\
\text { (Magna Cum Laude); Volvo do Brasil Veículos Ltda (Magna Cum Laude); } \\
\text { Centrais Elétricas do Norte do Brasil S.A. (Summa Cum Laude) }\end{array}$ \\
\hline
\end{tabular}

Source: Fundação Nacional da Qualidade (FNQ, 2016).

The first stage of the data analysis consisted of the analysis of the influence of the financial logic on the Management Excellence Model (MEM) versions in force from 1992 to 2016. It was sought to identify the presence in the fundamentals of excellence and criteria of excellence of concepts related to the need to generate value for shareholders, and to practice the basic principles of corporate governance of transparency, fairness, accountability and corporate responsibility. In addition, were analyzed, in terms of percentage, the participation of the criteria of excellence in the score systems in force from 1992 to 2016 , aiming to evaluate the relevance of each 
criterion and to verify if there was an increase of the representativeness of the criteria of excellence that present concepts of financial logic.

The second stage consisted in the characterization of the NQA-winning companies and in the identification of the influence of the financial logic in these organizations. Initially, the segments of the winning companies were classified using the sectorial classification of BM\&FBOVESPA (stock exchange) and the percentages of representativeness of each segment were determined.

The companies were classified in the segments of BM\&FBOVESPA as follows: Electric Utilities, Toll Roads and Highways, Consumer Non-Cyclical, Petrochemicals, Steel, Water Utilities, Beer and Soft Drinks, Banks, Aerospace and Defense, Metallic Minerals, Pulp and Paper, Software and Services, Diversified Services, Hardware and Equipments, Equipment and Services, Exploration and Refining, Agricultural and Construction Machinery, and Others.

Next, the professionals acting on the boards of directors and in the presidency of the award-winning organizations in the award years were identified, aiming to identify the occurrence of board interlocking, that is, common counselors and presidents in these organizations that could have influenced the MEM adoption and the participation in the NQA.

The occurrence of board interlocking in the award-winning companies shows how the connection between the counselors can influence the adoption and dissemination of certain reference models, besides contributing to the reproduction of the discourse of the shareholder value ideology. At that moment, were performed the following sequential activities: identification of the members of the award-winning companies that participate or participated in some NQF council, aiming to verify the key persons of these organizations who support or supported the NQF cause; identification of the persons who acted in the boards of directors and the presidency in the years in which the companies won; and identification of the board interlockings, that is, the presidents and common counselors, who acted during the award years of the award-winning organizations.

Finally, it was characterize the professional origin of the executive directors who acted in the award year of the winning companies. The areas in which these professionals acted before becoming presidents were categorized as follows: Operations, Sales, and Marketing and Finance, being the same used in Fligstein (1990). Finally, the educational background of these professionals on the graduate and postgraduate levels were evaluated and categorized in Engineering, Administration, Finance, and Others. This made possible the comparison of the representativeness, in percentage terms, of professionals who had professional origin in financial areas and educational background in finance.

\section{Analysis of the influence of financial logic on the Brazilian National Quality Award}

\subsection{The influence on the Management Excellence Model}

The analysis of the Management Excellence Model versions in terms of fundaments of excellence and criteria of excellence, in the period of 1992 to 2016, shows the progressive abandonment of the term "quality". The percentage of citations of this term in the titles of the criteria of excellence and the evaluation items were: 
$47 \%$ in the 1992 version; $37 \%$ in the versions from 1992 to 1996; and $0 \%$ in the versions in force from 1997.

The use of the term "quality" in the first versions was related to the following criteria of excellence: leadership; information and analysis; strategic quality planning; quality assurance of products and services; and quality results. This was due to a limited vision of these versions that the focus of the valuation criteria should be how a determined organization generates value to customers and meets the quality objectives, through a leadership committed to the subject, a strategic planning that incorporates quality improvement planning, and a quality assurance that meets the customers' requirements and expectations.

In addition, the analysis of the fundaments of excellence and the criteria of excellence versions showed that several concepts of financial logic were incorporated in the MEM, among which:

- Focus in the shareholder value creation, by identifying and analyzing the needs and expectations of this stakeholder and translating them into performance requirements, which are monitored by economic-financial indicators, that need to generate sustainable results;

- Corporate governance practices, aiming to guarantee transparency, equity, accountability and corporate responsibility;

- Strategic planning that aims to meet the requirements of all stakeholders, including those related to the shareholders;

- Fundaments of excellence which emphasize the need to meet and protect the interests of the stakeholders (fundaments: transformative leadership, systemic thinking, value generation) and to be agile in decision-making needed in a financial environment (fundament: agility).

The analysis of the scoring systems used in the Management Excellence Model versions showed an increase of the relative participation of the criteria of excellence and evaluation items that presented concepts related to financial logic (Table 1).

The leadership criterion presented a small increase of its relative participation in the scoring system, representing, as of the versions of $2006,11 \%$ of the maximum possible scoring to be obtained in the scoring system. The analysis of the weights of the evaluation items of this criterion allowed us to verify that the item called corporate governance, in force since 2008 represented $36 \%$ of the total score of the leadership criterion, demonstrating the relevance that this financial logic theme came to have in MEM.

The strategy and plans criterion had an increase of its representativeness in the versions from 1997 to 2005 , however, returning to represent $6 \%$ of the maximum possible scoring to be obtained in the scoring systems of the versions in force since 2006.

The information and knowledge criterion presented a reduction of its relative participation in the scoring system, being only $6 \%$ from the 2003 version.

The customers criterion was the one which presented the largest reduction of the relative participation in the scoring system, representing $30 \%$ in the initial MEM versions and representing only $6 \%$ of the total score in the versions in force since 2003. This demonstrates that the need to create value for other stakeholders, such as the shareholders, has become as relevant as customers value creation. 
The society criterion emerged from 2003 , representing $6 \%$ of the maximum score of the scoring systems, due to the need to incorporate the corporate governance principle regarding the corporate responsibility disseminated in the financial logic.

The processes criterion reduced its relative participation in the scoring system, being $14 \%$ in the initial MEM versions and becoming $11 \%$ in the versions in force from 2006. The analysis of the evaluation items of this criterion allowed us to verify the increase of the relevance of the economic-financial processes, and from the 2001 versions specific evaluation items were created to evaluate these processes, which represented $22 \%$ of the maximum score to be obtained in the processes criterion in the versions from 2001 to 2005 , and $27 \%$ in the following versions.

The people criterion presented a reduction in its weight in the scoring system, representing $15 \%$ of the maximum scoring to be obtained in the first versions and, from 1999, representing $9 \%$ of the total score.

The results criterion was the one that most presented an increase in its representativeness in the scoring system, ceasing to be only $18 \%$ of the total scoring to be equal or superior to $45 \%$ in the versions in force since 1997 . The economic-financial results became contemplated in a specific evaluation item of this criterion, representing more than $21 \%$ of the maximum possible score obtained in the results criterion, in the versions in force since 1998.

Table 1. Scoring systems of the Management Excellence Model versions.

\begin{tabular}{|c|c|c|c|c|c|c|c|}
\hline \multirow{2}{*}{$\begin{array}{l}\text { Criteria of } \\
\text { Excellence }\end{array}$} & \multicolumn{7}{|c|}{$\begin{array}{l}\text { Relative participation in the scoring systems of the Management } \\
\text { Excellence Model versions }\end{array}$} \\
\hline & 1992 & $\begin{array}{l}1993 \text { to } \\
1994\end{array}$ & $\begin{array}{l}1995 \text { to } \\
1996\end{array}$ & 1997 & $\begin{array}{l}1998 \text { to } \\
2002\end{array}$ & $\begin{array}{l}2003 \text { to } \\
2005\end{array}$ & $\begin{array}{l}2006 \text { to } \\
2016\end{array}$ \\
\hline Leadership & $10 \%$ & $9,5 \%$ & $9 \%$ & $11 \%$ & $9 \%$ & $10 \%$ & $11 \%$ \\
\hline $\begin{array}{l}\text { Strategies and } \\
\text { Plans }\end{array}$ & $6 \%$ & $6 \%$ & $5,5 \%$ & $8 \%$ & $9 \%$ & $9 \%$ & $6 \%$ \\
\hline Customers & $30 \%$ & $30 \%$ & $25 \%$ & $8 \%$ & $9 \%$ & $6 \%$ & $6 \%$ \\
\hline Society & $0 \%$ & $0 \%$ & $0 \%$ & $0 \%$ & $0 \%$ & $6 \%$ & $6 \%$ \\
\hline $\begin{array}{l}\text { Information and } \\
\text { Knowledge }\end{array}$ & $7 \%$ & $7,5 \%$ & $7,5 \%$ & $8 \%$ & $9 \%$ & $6 \%$ & $6 \%$ \\
\hline Processes & $14 \%$ & $14 \%$ & $14 \%$ & $10 \%$ & $9 \%$ & $9 \%$ & $11 \%$ \\
\hline People & $15 \%$ & $15 \%$ & $14 \%$ & $10 \%$ & $9 \%$ & $9 \%$ & $9 \%$ \\
\hline Results & $18 \%$ & $18 \%$ & $25 \%$ & $45 \%$ & $46 \%$ & $45 \%$ & $45 \%$ \\
\hline
\end{tabular}

Source: elaborated by the authors.

It is worth mentioning that the progressive abandonment of the use of the term "quality" and the reduction of the representativeness of the customers criterion in the scoring systems are reflections of the strategy used by NQA to change its identity, which, was initially aimed at promoting the quality and started to focus on promoting the excellence in management. 


\subsection{The influence on companies awarded the Brazilian National Quality Award}

\subsubsection{Profile of the award-winning companies}

Initially, were classified the segments of all companies winners of the NQA. Figure 1 demonstrates that the Electric Utilities segment represented $32 \%$ of the companies winners of the NQA.

\section{Categorization of the segments of the organizations winners of the NQA (1992-2016)}

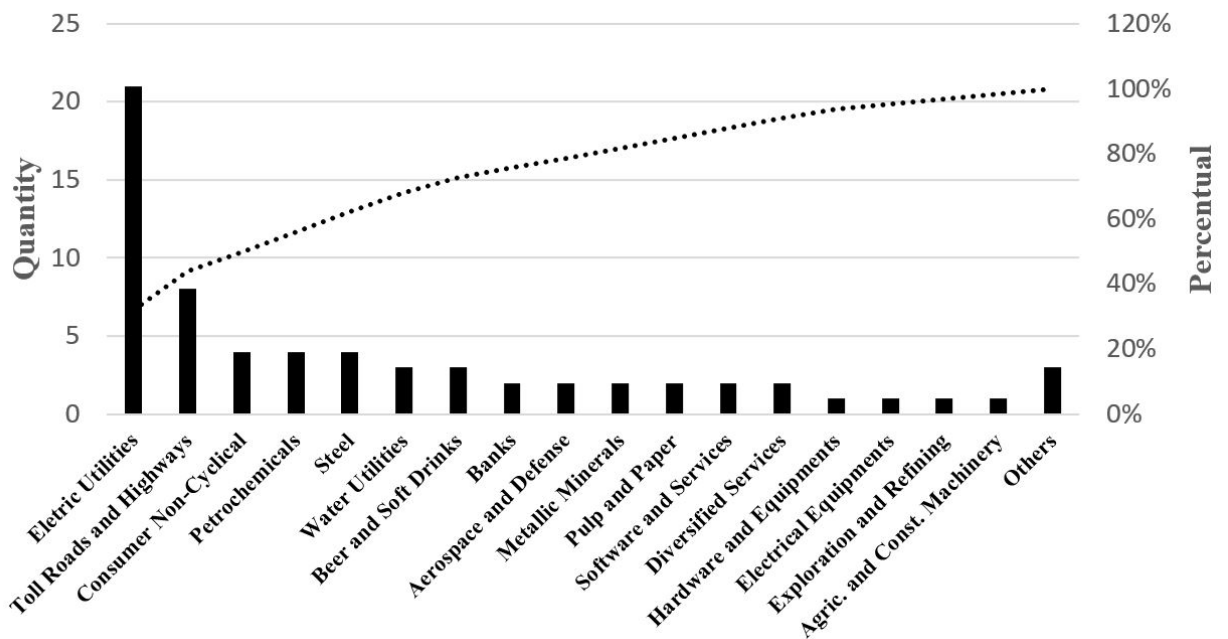

Figure 1. Categorization of the segments of the organizations winners of the NQA. Source: elaborated by the authors.

Most of the companies winners of the Electric Energy segment $(77 \%)$ were privatized by the late 1990s, and those awards took place after the privatizations occurred, mostly in the late 2000s. It is worth to emphasize that obtaining the NQA is a way for the management to maintain the legitimacy of these organizations after their privatization. Recognition is used as a way of providing an answer to the external demands of the new owners (shareholders) who started to demand a more efficient administration, with reduced cost structure. Grün (2011) demonstrates this transition that occurred in Brazil with the wave of privatizations, which led to a transition from an organization named by the author of Model 1 of companies, of managers and engineers, to the Model 2, that refers to a greater performance of the financial area and focus on the shareholder value creation. The $23 \%$ of the Electric Energy companies that were not privatized when they were awarded (Cemig Geração e Transmissão S.A., one time awarded, and Centrais Elétricas do Norte S.A, awarded four times) have been or are undergoing privatization processes.

The analysis of the profile of the organizations awarded prizes in the NQA demonstrates another interesting aspect; several of these organizations present relations among themselves, either by participating in the same business group, or by having been acquired by other business groups that already had a history of having NQA award-winning companies. 
Among the business groups that had more than one company or business unit of the group awarded the NQA are:

- CPFL Energia: includes CPFL Paulista, CPFL Piratininga and RGE;

- AES Brasil: includes AES Eletropaulo, AES Sul and AES Tietê;

- Suzano: includes Suzano Papel e Celulose and Suzano Petroquímica;

- Randon: includes Fras-le, Suspensys and Master Sistemas Automotivos;

- Gerdau: includes Piratini and Riograndense units;

- Promon: includes Promon and Promon Logicalis;

- Sabesp: includes Sebesp Norte, Sabesp Leste and Sabesp Sul.

The analysis of the organizations profiles allowed to identify the existence of certain business groups that acquired companies awarded in the NQA.

- Suzano: acquired the award-winning companies Politeno Indústria e Comércio S.A. and Bahia Sul Celulose S.A., and sold the award-winning company Suzano Petroquímica to Petrobras and, two years after the purchase, sold the company Politeno Indústria e Comércio S.A. to Braskem, which takes part of the Oderbrecht S.A. group;

- Oderbrecht S.A.: aiming the diversification of Braskem products, this business group acquired the award-winning companies: Politeno Indústria e Comércio S.A., which had been acquired by the Suzano group; Petroquímica do Sul (Copesul); Petroquímica União S.A.; Suzano Petroquímica, which had been first acquired by Petrobras. In addition, this business group includes the Cetrel S.A., which is an award-winning company;

- CPFL Energia: acquired the award-winning company AES Sul.

In addition, it allows to verify that some business groups and award-winning companies have gone or are undergoing sales processes such as:

- CPFL Energia: sold to State Grid;

- AES do Brasil: aproximately $70 \%$ of Eletropaulo sold to Enel;

- Oderbrecht S.A.: negotiating the sale of Braskem to LyondellBasell;

- Embraer S.A.: negotiating the sale of the Commercial Aviation business unit to Boeing.

These merger and acquisition processes are aligned with the financial conception of control, which seeks to operate in many companies, resulting in multiple mergers. The diversification also becomes a strategy of the organizations to reduce business risks. In addition, these mergers are also consistent with the shareholders capitalism, which encourages the divestment in non-productive lines and investment in dominant businesses, seeking the rise of share prices.

\subsubsection{Identification of professionals acting in the boards of directors and in the presidency of winning organizations}

Initially were identified the members of award-winning companies that acted as members of NQF boards. It was verified that $61 \%$ of the award-winning organizations had members of their top management acting in various boards and fronts of NQF in the period from 1992 to 2016. 
Subsequently were identified the members who acted in the board of directors of the companies in the years in which they were awarded. Then, were identified the common professionals who acted in more than one award-winning organization as presidents or conselours. Figure 2 presents six professionals who had a strong role as couselors in NQF and in award-winning companies, as presidents and/or as members of the board of directors of these companies.

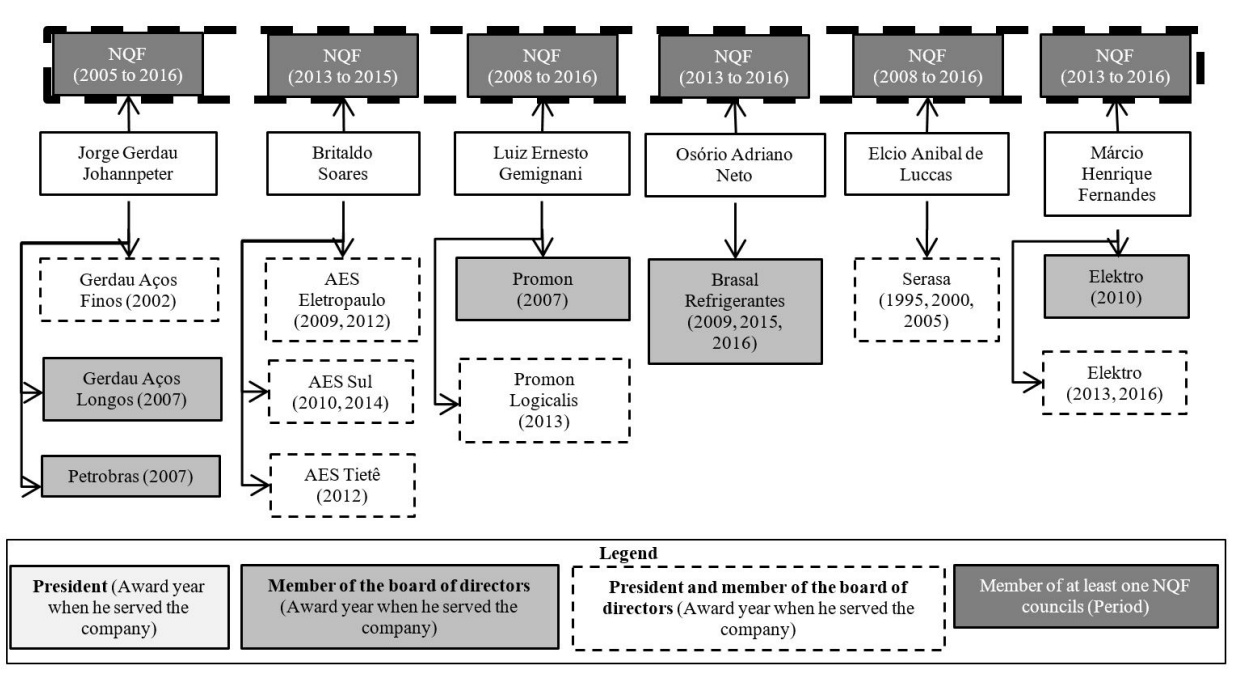

Figure 2. Board interlocking of professionals of the award-winning companies (Part 1). Source: elaborated by the authors.

Jorge Gerdau Johannpeter is one of the main diffusers of the quality movement in Brazil. He was the founder of the Gaúcho Quality and Productivity Program, and the Brazil Competitive Movement. In addition to being member of the Brazilian International Academy of Quality, the Brazilian Academy of Quality and the Notables Council of NQF. In 2002, he served as president and member of the board of directors at Gerdau Aços Finos, which received the NQA that year. In 2007, he acted in the board of directors at some award-winning companies (Gerdau Aços Longos and Petrobras).

Britaldo Soares acted as president and member of the board of directors at companies of the AES Brasil group, which includes the award-winning companies: AES Eletropaulo, AES Sul and AES Tietê. He also acted in the NQF Curator Council.

Luis Ernesto Geminiani was president of Promon S.A. in the period from 2001 to 2010, member of the board of directors of the group since 2007 and of the NQF Curator Council since 2008. Promon was awarded in 2007 and Promon Logicalis in 2013.

Osório Adriano Neto acts as major shareholder and vice president of the Brasal Group and as member of the board of directors at the award-winning Brasal Refrigerantes. Osório contributed to the diffusion of the quality movement in Brazil, through the participation in the NQF boards and in the Fiscal Council of the Brazil Competitive Movement.

Élcio Annibal de Luccas was also one of the diffusers of the quality movement in Brazil, through acting in the NQF boards and in the foundation and presidency of the Brazil Competitive Movement. His professional career was, mainly at Serasa S.A, 
which is one of the few companies that conquered for three times the NQA, having acted as president and member of the board of directors at this company.

Márcio Henrique Fernandes, member of the Curator Council of NQF, acted in the presidency and in the board of directors at Elektro in the company's award winning years.

It could be observed that these five professionals had direct contacts in the NQF, as they acted, for several years, as members of the Curator Council of NQF, inclusive in common mandates, which lasts three years each. This board interlocking favored the sharing and diffusion of management practices.

Figure 3 presents five professionals who formed a board interlocking by having been members of the same mandates on the NQF councils and/or in the boards of directors at some award-winning organizations.

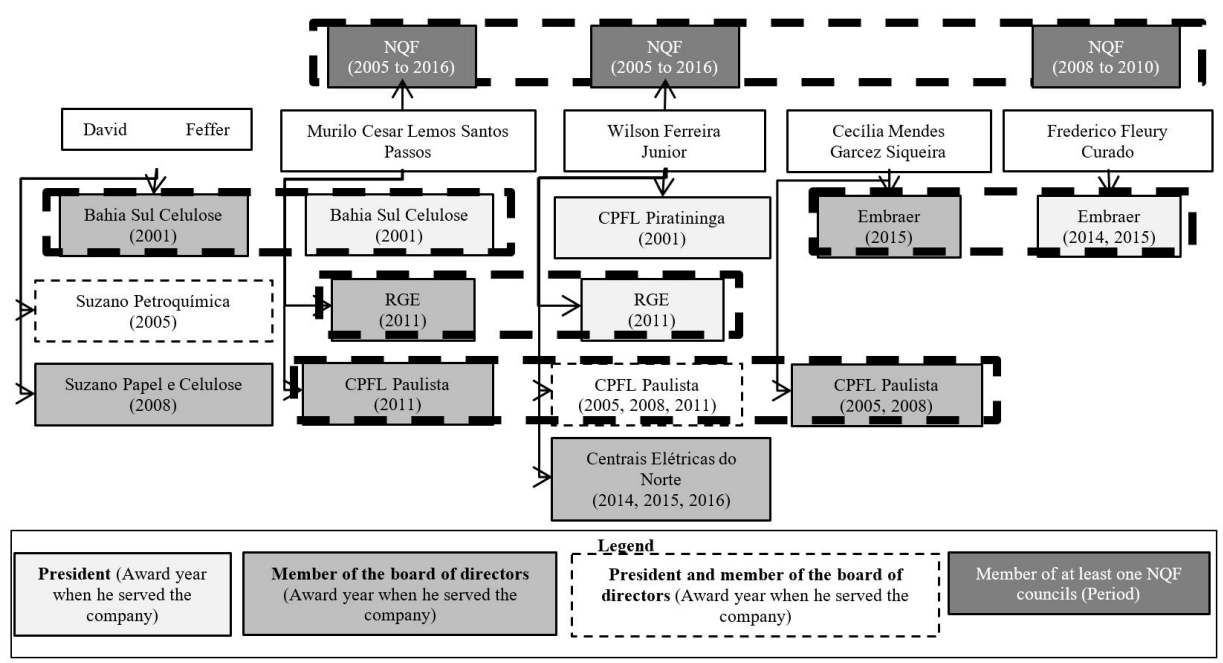

Figure 3. Board interlocking of professionals of the award-winning companies (Part II). Source: elaborated by the authors.

David Feffer served in the boards of directors at some award-winning companies, such as Bahia Sul Celulose, Suzano Petroquímica and Suzano Papel e Celulose. In 2001, David Feffer was a member of the board of directors of Bahia Sul Celulose in the same period that Murilo Cesar Lemos Santos Passos served in this board.

Murilo Cesar Lemos Santos Passos was, from 1992 to 2006, Superintendent Director at Bahia Sul Celulose S.A and Suzano Papel e Celulose. He serves as the member of Management Committee at Suzano Papel and Celulose S.A., and chairman of the board of directors at CPFL Energia since 2010, which is one of the groups that most presented NQP-winning companies, such as: CPFL Paulista (three times winner) and Rio Grande Energia (RGE) among others. Murilo Passos is one of the main diffusers of the MEM, which made him a member of the Notables Council of NQF.

Murilo Passos, during his performance as president on the board of directors at CPFL Energia had contact with Wilson Ferreira Junior, who was president at Rio Grande Energia (RGE) in 1998, and, from 2000, was president of the CPFL Energia group.

Wilson Ferreira Junior led the transformation occurred in the CPFL Energia group, being the main sponsor of the MEM implementation in the companies of the group, 
which resulted in the awards in the NQA of the following companies: CPFL Piratininga, Rio Grande Energia (RGE) and CPFL Paulista. In addition, he served as president of the Associação Brasileira dos Distribuidores de Energia (ABRADEE), which is one of the main players that contributed to the diffusion of MEM in the companies of the Electric Utilities segment and encouraged the participation of these companies in the NQA. He also served, for several years, on the NQF's Board of Trustees, including as chairman of this council, and as vice president of the Superior Council of the Brazil Competitive Movement. In mid-2016 served as chairman at the Eletrobras group, which includes the company Centrais Elétricas do Norte, where he serves in the board of directors since 2014 , which is is the first and only company to receive the maximum NQF recognition called summa cum laude in 2016.

Cecilia Mendez Garcez Siqueira served in the board of directors at CPFL Paulista in the years in which the company won the NQA for the second and third times (2005 and 2008). In this council, she had contact with the promoters of adoption of MEM Murilo Passos and Wilson Ferreira Junior. In addition, Cecilia Siqueira served on Embraer's board of directors in the year in which the company won the NQA's magna cum laude recognition, for having been awarded in 2014 and maintained the excellence level in 2015.

At Embraer, Cecilia Siqueira had contact with the president of the organization, Frederico Curado, who was the sponsor of the MEM implementation at the organization, having also acted on the NQF Curator Council from 2008 to 2010.

Figure 4 shows three professionals who formed a board interlocking because they were members on common mandates of the boards of directors at some award-winning organizations.
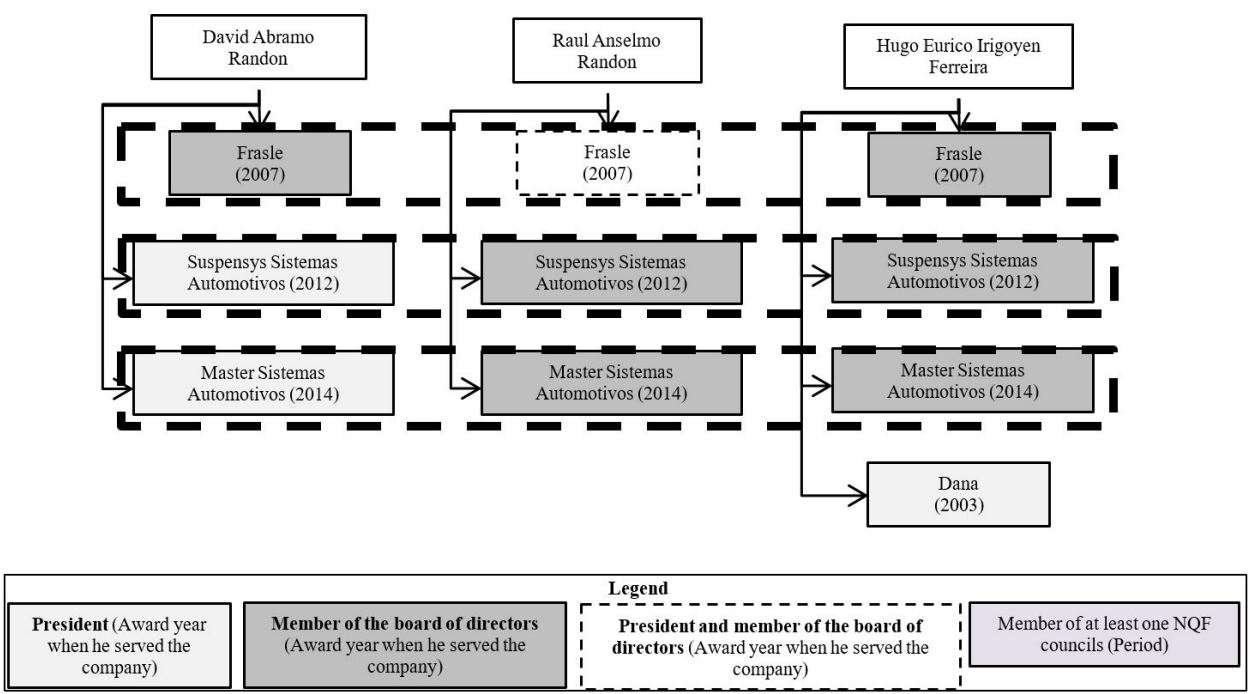

Figure 4. Board interlocking of professionals of the winning companies (Part III). Source: elaborated by the authors.

Hugo Eurico Irigoyen Ferreira was president of Dana, being responsible for disseminating the culture of quality, which culminated in several awards, including NQA. Then, Hugo Ferreira became a member of the board of directors at the Randon Group, having served in this board in the years in which the companies of the group 
were awarded in the NQA, among them: Fras-le, Suspensys Sistemas Automotivos and Master Sistemas Automotivos.

David Abramo Randon and Raul Anselmo Randon served as chairmen and members of the board of directors at companies of the Randou Group which won the NQA (Fras-le, Suspensys Sistemas Automotivos and Master Sistemas Automotivos).

\subsubsection{Characterization of the professional origin of the presidents of the organizations}

The analysis of professional profile of the presidents of the winning companies, in the period 1992-2016, showed that $43 \%$ came from Financial areas, 30\% from Operations, $12 \%$ fom Sales and Marketing and $15 \%$ from other areas. The high representativeness of presidents who presented in their professional trajectory the performance in financial areas shows the tendency verified by Fligstein $(1990,2001)$ and by Salento \& Masino (2011) that, in the financial conception of control there is the predominance of managers with economic-financial experience, replacing managers from technical areas.

Later, the educational backgrounds (graduate and postgraduate levels) of these presidents were analyzed. In general, the graduate level of these presidents were distributed in: Engineering (59\%), Finance (14\%), Administration (12\%), Other courses $(11 \%)$ and Not possible to identify (4\%). In addition, the posgraduate level were distributed in: Finance (35\%), Administration (32\%), Engineering (9\%), Other courses $(7 \%)$ and Not possible to identify (17\%). It is worth noting that $61 \%$ of professionals who opted for postgraduation in Finance, graduated in Engineering.

This result is consistent with Matsuda (2015), which demonstrated that Engineering is one of the elite careers in Brazil, which ends up having a prominent position in tems of preference in hiring processes of the companies. However, this author uses Jardim (2011) to explain that this predominance of engineers in the financial conception of control needs to be analyzed under the view that the professionals are the same, but act differently to maintain the elite positions.

According to Jardim (2011) with the crisis of fordism there is a reconversion of engineers to the financial market, to the extent that they need to acquire more extensive knowledge and skills related to the commercial, managerial, administrative and financial areas. Thus, they seek to acquire knowledge in finance, either through acting in financial areas or by the seeking postgraduations in finance.

\section{Conclusion}

The analysis of the MEM showed that the first versions had focused in the diffusion of the quality management practices, emphasizing the need to meet the demands and expectations of customers, and the quality objectives. However, it was verified that the MEM versions were gradually incorporating concepts of financial logic such as: need to generate value to the shareholders; meet the corporate governance principles; have a strategic planning that seeks to meet the requirements of all stakeholders and not only quality objectives; need to meet and protect the interests of the stakeholders; and to be agile and assertive in a financialized environment. In addition, it is important to mention the disuse of the term "quality" in the MEM versions from 1997. 
Thus, the incorporation of these concepts of financial logic and the disuse of the term "quality" araised from the NQF needs to maintain its legitimacy and to guarantee the "survival" of the reference model. Hence, the MEM has been updated, aiming to be aligned to the financial logic, but not necessarily guaranteeing the organizational efficiency. A fact that reinforces this remodeling was the alteration of the NQA name in 2017 to "Best in Management", which was the only place that the term "quality" was still referenced.

This raises an interesting discussion whether MEM would not have ceased being a quality management model and become one more financial logic model, being, according to the theory of Strategic Action Fields addressed by Fligstein \& McAdam (2012), resulting from a change in the internal dynamics of operation of the "denominated" field, in this case, the quality management field, which needs to find new ways to survive in face of the exogenous shocks and collisions of the "dominating" field related to financialization.

It was observed the predominance of companies of the Electric Utilities segment awarded the NQA, most of which went through privatizations in the 1990s and were awarded after this process. This change of ownership is a mark in the transition of the capital accumalation from production logic to financial logic.

It was verify the financialization of the NQA, due to the ascendancy of the shareholder value orientation as a guiding principle of corporate behavior. Hence, the organizations seek to maintain their legitimacy by obtaining recognitions that are considered legitimate in the financial logic, such as the NQA revitalized, which favor companies that have management practices and results that seek to shareholder value creation.

The analysis of the boards of directors and presidents showed that more than twenty award-winning companies have professionals acting on various NQF boards, demonstrating that not only the MEM has started to influence the organizations, but also the organizations began to influence this model. The leaders of these award-winning organizations, that acted in the NQF, contributed to the financilization of the MEM.

In addition, were identified practices of board interlocking of common members who acted in the NQF boards, board of directors and presidency of award-winning companies. This contributed to the occurrence of the normative isomorphism in these organizations, which, according to DiMaggio and Powell (1991), is associated to the establishment of professional networks that act in the organizations and contribute to the rapid diffusion of models considered legitimate.

Finally, the professional and educational backgrounds of the presidents, who served during the years in which the companies were awarded, were analyzed. This analysis was motivated by the study of Fligstein (1990), which reported that in the financial conception of control there is a tendency to privilege professionals who present functional background in financial areas and educational background in finance. Thus, was observed the predominance of professionals who came from financial areas before becoming presidents of the award-winning companies, confirming the results of Fligstein (1990) and the study that analyzed the Brazilian reality, such as Matsuda (2015).

The presidents of the award-winning organizations, which in their vast majority present professional and educational backgrounds in finance, have found a "new model of the financial logic", called MEM, that emerged from the need to maintain its legitimacy in the face of the decline of the quality movement. 


\section{References}

Aitken, R. (2007). Performing capital: toward a cultural economy of popular and global finance. New York: Palgrave Macmillan. http://dx.doi.org/10.1057/9780230607088.

Andersson, T., Haslam, C., Lee, E., Katechos, G., \& Tsitsianis, N. (2010). Corporate strategy financialized: conjuncture, arbitrage and earnings capacity in S\&P500. Accounting Forum, 34(3-4), 211-221. http://dx.doi.org/10.1016/j.accfor.2010.08.002.

Arrighi, G. (1994). The long twentieth century: money, power and the origins of our times. New York: Verso.

Bassan, H. (2016). Gestão pela qualidade total e desempenho financeiro: um estudo da geração de riqueza ao acionista em empresas vencedoras de prêmios nacionais da qualidade do continente americano (Tese de doutorado). Universidade Federal de São Carlos, São Carlos.

Bassan, H., \& Martins, R. A. (2015). Geração de riqueza em empresas vencedoras do PNQ: uma análise usando o EVA. Production, 26(1), 203-217. http://dx.doi.org/10.1590/01036513.115413.

Boulter, L., Bendell, T., \& Dahlgaard, J. J. (2013). Total quality beyond North America: a comparative analysis of the performance of European Excellence Award winners. International Journal of Operations \& Production Management, 33(2), 197-215. http://dx.doi.org/10.1108/01443571311295635.

Bourdieu, P. (2010). O poder simbólico. Rio de Janeiro: Bertrand Brasil.

Boyer, R. (2000). Is a finance-led growth regime a viable alternative to fordism? A preliminary analysis. Economy and Society, 29(1), 111-145. http://dx.doi.org/10.1080/030851400360587.

Braga, J. C. S. (1997). Financeirização global: o padrão sistêmico de riqueza do capitalismo contemporâneo. In M.C. Tavares, J.L. Fiori (Eds.), Poder e dinheiro: uma economia política da globalização. Petrópolis: Vozes.

Casado, P. C., \& Legaz, S. G. (2010). Quality awards and performance: is there a relationship? The TQM Journal, 22(5), 529-538. http://dx.doi.org/10.1108/17542731011072865.

Chaudary, S., Zafar, S., \& Salman, M. (2015). Does total quality management still shine? Reexamining the total quality management effect on financial performance. Total Quality Management \& Business Excellence, 26(8), 811-824. http://dx.doi.org/10.1080/14783363.2014.895521.

Chesnais, F. (1996). Financeirização: a mundialização do capital. São Paulo: Xamã.

Chesnais, F. (Coord.), (2005). A mundialização financeira: raízes sociais e políticas, configuração consequências. São Paulo: Boitempo.

Corredor, P., \& Goñi, S. (2010). Quality awards and performance: is there a relationship? The TQM Journal, 22(5), 529-538.

Davis, G. F. (2009). Managed by the markets. New York: Oxford University Press.

DiMaggio, P. J., \& Powell, W. W. (1991). The iron cage revisited: institutional isomorphism and collective rationality in organizational fields. In W. W. Powell \& P. J. Dimaggio (Eds.), The New Institutionalism in Organizational Analysis. Chicago: University of Chicago Press.

Donadone, J. C. (2009). Lógica financeira e dinâmica organizacional nos anos 1990: novos donos, novos consultores, outros gerentes. In Q. P. C. Mondadore, A. J. Pedroso Neto, E. S. Leite, M. A. C. Jardim \& M. S. Sartore (Orgs.), Sociologia econômica e das finanças: um projeto em construção (pp. 133-153). São Carlos: EdUFSCar.

Donadone, J. C., \& Cenedezi, V. (2016). Inserção, atuação e ascensão profissional: o papel do capital social em usinas sucroalcooleiras do interior paulista. Revista Eletrônica de Administração, 15(2), 173-193. Retrieved in 2016, December 6, from http://periodicos.unifacef.com.br/index.php/rea/article/view/1101/946 
Donadone, J. C., \& Fantti, M. B. L. (2014). Intermediários, lógica financeira e a reconfiguração da "qualidade" no tecido organizacional brasileiro. In Proceedings of the IX Workshop Empresa, Empresários e Sociedade. São Paulo: WEES.

Engelen, E. (2008). The case for financialization. Competition \& Change, 12(2), 111-119.

Epstein, G. (2005). Financialization and the world economy. Inglaterra: Edward Elgar.

Erturk, I., Froud, J., Johal, S., Leaver, A., \& Williams, K. (2007). The democratisation of finance? Promises, outcomes and conditions. Review of International Political Economy, 14(4), 553-575. http://dx.doi.org/10.1080/09692290701475312.

Erturk I., Froud, J., Johal, S., Leaver, A., \& Williams, K. (2008). Financialization at work: key texts and commentary. Nova York: Routlegde.

Fich, E. M., \& White, L. J. (2005). Why do CEOs reciprocally sit on each other's boards? Journal of Corporate Finance, 11(1-2), 175-195. http://dx.doi.org/10.1016/j.jcorpfin.2003.06.002.

Fligstein, N. (1990). The transformation of corporate control. Nova York: Oxford University Press.

Fligstein, N. (2001). The architecture of markets: an economic sociology of twenty-first-century capitalist societies. Princeton: Princeton University. http://dx.doi.org/10.1515/9780691186269.

Fligstein, N., \& McAdam, D. (2012). A theory of fields. Nova York: Oxford University Press. http://dx.doi.org/10.1093/acprof:oso/9780199859948.001.0001.

Froud, J., Haslam, C., Johal, S., \& Williams, K. (2006). General eletric: the conditions of success. In J. Froud, C. Haslam, S. Johal, \& K. Williams (Eds.), Financialisation and strategy: narrative and numbers (pp. 299-388). London: Routledge. http://dx.doi.org/10.4324/9780203414941-8.

Froud, J., Johal, S., Leaver, A., \& Williams, K. (2012). Apple business model: financialization across the Pacific. (CRESC Working Paper Series, No. 111, pp. 1-28). Manchester: CRESC.

Fundação Nacional da Qualidade - FNQ. (2013). Critérios de excelência: avaliação e diagnóstico da gestão organizacional. São Paulo: Fundação Nacional da Qualidade.

Fundação Nacional da Qualidade - FNQ. (2015). Questão de excelência. Revista Classe Mundial, 16(16), 39-45.

Fundação Nacional da Qualidade - FNQ. (2016). A força da gestão. Revista Classe Mundial, 17(17), 27.

Goldstein, A. (2012). Revenge of the managers: labor cost-cutting and the paradoxical resurgence of managerialism in the SHV era, 1984 to 2001. American Sociological Review, 77(2), 268-294. http://dx.doi.org/10.1177/0003122412440093.

Grigg, N., \& Mann, R. (2008). Rewarding excellence: an international study into business excellence award processes. The Quality Management Journal, 15(3), 26-40. http://dx.doi.org/10.1080/10686967.2008.11918193.

Grün, R. (2004). A evolução recente do espaço financeiro no Brasil e alguns reflexos na cena política. Dados - Revista de Ciências Sociais, 47(1), 5-47.

Grün, R. (2011). Modelos econômicos e modelos de mundo. In J. C. Donadone, M. A. C Jardim (Eds.), As centralidades e as fronteiras das empresas do século 21 (pp. 27-61). Bauru: Edusc.

Hendricks, K. B., \& Singhal, V. R. (1996). Quality awards and the market value of the company: an empirical investigation. Management Science, 42(33), 415-437. http://dx.doi.org/10.1287/mnsc.42.3.415.

Hendricks, K. B., \& Singhal, V. R. (1997). Does implementing an effective TQM program actually improve operating performance? Empirical evidence from firms that have won 
quality awards. Management Science, 43(9), 1258-1274.

http://dx.doi.org/10.1287/mnsc.43.9.1258.

Jardim, M. A. C. P. (2011). Presença de centrais e sindicatos no mercado financeiro: criação e gestão de fundos de pensão. Estudos de Sociologia, 16, 20-30.

Jürgens, J., Naumann, K., \& Rupp, J. (2000). Shareholder value in an adverse environment: the German case. Economy and Society, 29(1), 54-79. http://dx.doi.org/10.1080/030851400360569.

Lazonick, W. (2008). The quest for shareholder value: stock repurchases in the U.S. economy. Louvain Economic Review, 74(4), 479-540. http://dx.doi.org/10.3917/rel.744.0479.

Lazonick, W., \& O'Sullivan, M. (2000). Maximizing shareholder value: a new ideology for corporate governance. Economy and Society, 29(1), 13-35. http://dx.doi.org/10.1080/030851400360541.

Martin, R. (2002). Financialization of daily life. Filadélfia: Temple University Press.

Matsuda, P. M. (2015). O impacto do processo de financeirização sobre a estrutura social nas empresas: estudo de caso do setor elétrico paulista (Tese de doutorado). Universidade Federal de São Carlos, São Carlos.

Mavroidis, V., Toliopoulou, S., \& Agoritsas, C. (2007). A comparative analysis and review of national quality awards in Europe. The TQM Magazine, 19(5), 454-467. http://dx.doi.org/10.1108/09544780710817874.

Montgomerie, J. (2006). The financialization of the american credit card industry. Competition \& Change, 10(3), 301-319. http://dx.doi.org/10.1179/102452906X114393.

Mundo, M., No. (2011). A lógica financeira e o espaço do transporte aéreo comercial brasileiro. Gestão \& Produção, 18(2), 311-324. http://dx.doi.org/10.1590/S0104$530 \times 2011000200007$.

Mundo, M., No. (2012). Transformações na indústria sucroalcooleira brasileira no início do século XXI: das famílias aos acionistas (Tese de doutorado). Universidade Federal de São Carlos, São Carlos.

Nair, A. (2006). Meta-analysis of the relationship between quality management practices and firm performance - Implications for quality management theory development. Journal of Operations Management, 24(6), 948-975. http://dx.doi.org/10.1016/j.jom.2005.11.005.

Oliveira, G. T., \& Martins, R. A. (2008). Efeitos da adoção do modelo do Prêmio Nacional da Qualidade na medição de desempenho: estudos de caso em organizações ganhadoras do prêmio. Gestão \& Produção, 15(2), 247-259. http://dx.doi.org/10.1590/S0104530X2008000200004.

Pignanelli, A. (2007). Qualidade x desempenho: mito ou realidade? (Dissertação de mestrado). Fundação Getúlio Vargas, São Paulo.

Plihon, D. (2003). Le nouveau capitalisme. Paris: La Découverte.

Salento, A., \& Masino, G. (2011). Financialization and organizational change: a comparative study on multinational enterprises. In Proceedings of the 7th International Critical Management Studies Conference. Nápolis: CMS.

Saltorato, P., \& Benatti, G. (2017). O ato performático da reestruturação organizacional sob a ideologia da gestão baseada em valor. Revista Brasileira de Gestão de Negócios, 19(64), 263-288. http://dx.doi.org/10.7819/rbgn.v19i64.2875.

Saltorato, P., Domingues, L. C., Donadone, J. C., Sanches, E. C., \& Sola, F. (2016). Fusões, aquisições e difusão da lógica financeira sobre as operações de varejo brasileiro. Gestão \& Produção, 23(1), 84-103. http://dx.doi.org/10.1590/0104-530X780-15.

Souza, J. F. D. (2007). Integração vertical e financeirização: o caso da agroindústria processadora de grãos no Brasil (Dissertação de mestrado). Universidade Federal de São Paulo, São Paulo. 
Thompson, P. (2013). Financialization and the workplace: extending and applying the disconnected capitalism thesis. Work, Employment and Society, 27, 472-488. https://doi.org/10.1177/0950017013479827.

van der Zwan, N. (2014). Making sense of financialization. Socio-economic Review, 12(1), 99129. http://dx.doi.org/10.1093/ser/mwt020.

Westphal, J., \& Zajac, E. (2001). Decoupling policy from practice: the case of stock repurchase programs. Administrative Science Quarterly, 46(2), 202-228. http://dx.doi.org/10.2307/2667086.

Widmer, F. (2011). Institutional investors, corporate elites and the building of a market for corporate control. Socio-economic Review, 9(4), 671-697. http://dx.doi.org/10.1093/ser/mwr014.

Zajac, E., \& Westphal, J. (2004). The social construction of market value: institutionalization and learning perspectives on stock market reactions. American Sociological Review, 69(3), 433-457. http://dx.doi.org/10.1177/000312240406900306.

Zanarotti, V. R. C. (2012). Inserção, atuação e ascensão profissional: o papel do capital social em usinas sucroalcooleiras do interior paulista (Tese de doutorado). Universidade Federal de São Carlos, São Carlos.

Zhang, G. P., \& Xia, Y. S. (2013). Does quality still pay? A reexamination of the relationship between effective quality management and firm performance. Production and Operations Management, 22(1), 120-136. http://dx.doi.org/10.1111/j.1937-5956.2012.01341.x. 